\title{
Review
}

\section{Synthetic Routes to Arylsulfonyl Fluorides}

\author{
Aida Chelagha, Dan Louvel, Alexis Taponard (1), Rodolphe Berthelon and Anis Tlili *(1)
}

check for updates

Citation: Chelagha, A.; Louvel, D.; Taponard, A.; Berthelon, R.; Tlili, A Synthetic Routes to Arylsulfonyl Fluorides. Catalysts 2021, 11, 830. https://doi.org/10.3390/ catal11070830

Academic Editor:

Jean-Marc Campagne

Received: 22 June 2021

Accepted: 6 July 2021

Published: 8 July 2021

Publisher's Note: MDPI stays neutral with regard to jurisdictional claims in published maps and institutional affiliations.

Copyright: (c) 2021 by the authors. Licensee MDPI, Basel, Switzerland. This article is an open access article distributed under the terms and conditions of the Creative Commons Attribution (CC BY) license (https:// creativecommons.org/licenses/by/ $4.0 /)$.
Institute of Chemistry and Biochemistry (ICBMS-UMR CNRS 5246) University Lyon, Université Lyon 1, CNRS, CPE-Lyon, INSA43 Bd du 11 Novembre 1918, 69622 Villeurbanne, France; aida.chelagha@etu.univ-lyon1.fr (A.C.); dan.louvel@univ-lyon1.fr (D.L.); alexis.taponard@etu.univ-lyon1.fr (A.T.); rodoberthelon@gmail.com (R.B.)

* Correspondence: anis.tlili@univ-lyon1.fr; Tel.: +33-04-72-44-85-28

Abstract: The goal of this mini-review is to shed the light on the existing methodologies to access arylsulfonyl fluorides. Today, a plethora of methods making use of a different pool of starting materials and in the presence of catalyst or under catalyst free conditions are disclosed in the literature.

Keywords: fluorine; catalysis; sulfonyl fluorides; organic synthesis

\section{Introduction}

Arylsulfonyl fluorides are of prime interest in modern organofluorine chemistry. In fact, $\mathrm{RSO}_{2} \mathrm{~F}$ molecules are finding a plethora of applications in life science technologies [1-6]. Molecules bearing sulfonyl fluorides are employed as protease inhibitors, covalent protein modifiers and covalent protein inhibitors, as well as biological probes [7-11]. More recently, sulfonyl fluorides have been used in polyethylene terephthalate (PET), potential ${ }^{18}$ F-labelled biomarkers [12,13], polymerization [14-16] and sulfur (VI) exchange (SuFEx) "click chemistry" [17-20] (Scheme 1). Arysulfonyl fluorides have also been used as fluorinating agents through the deoxyfluorination of alcohols [21,22]. The strong nature of the S-F bond confers to sulfonyl fluoride's considerable stability in comparison to other sulfonyl halides. Indeed, to some extent, they are stable towards hydrolysis [23-26], resistant to reduction [27] and resistant to bond cleavage under transition-metal catalysis [28]. Despite the interest, methods for the synthesis of sulfonyl fluorides remain limited. The goal of this mini-review is to highlight the existing methodologies to access such compounds.
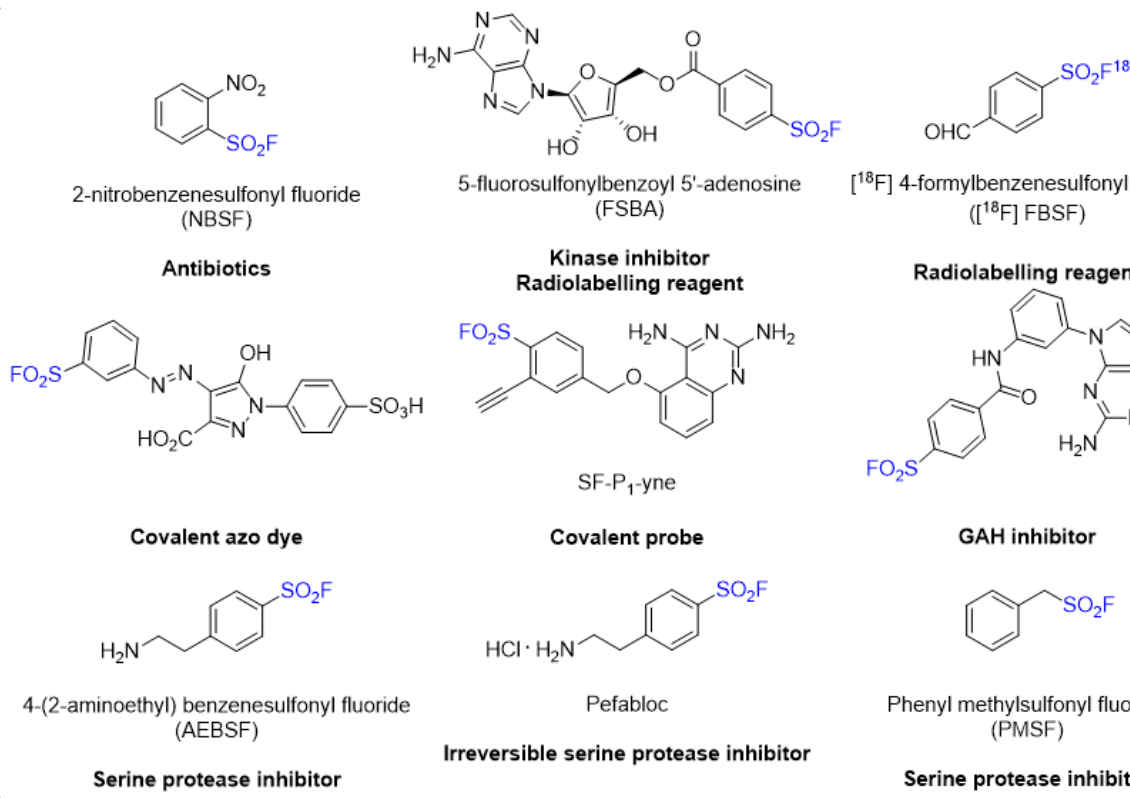

5-fluorosulfonylbenzoyl 5'-adenosine $\quad\left[{ }^{18} \mathrm{~F}\right] 4$-formylbenzenesulfonyl fluoride (FSBA) $\left(\left[{ }^{18} \mathrm{~F}\right] \mathrm{FBSF}\right)$

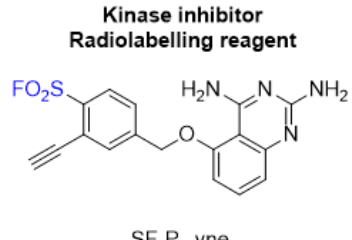

SF-P - yne

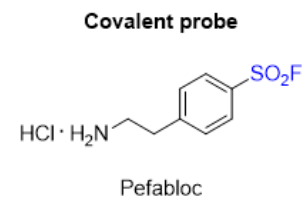

Irreversible serine protease inhibitor

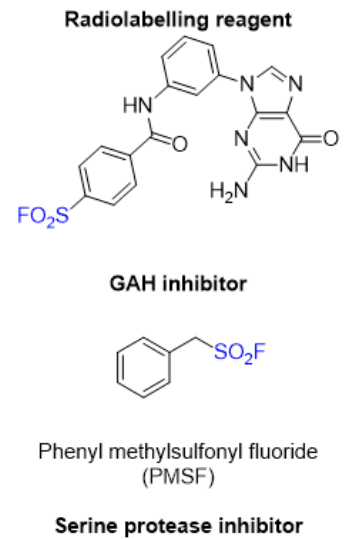

Scheme 1. A selection of arylsulfonyl fluorides with significant biological value. 


\section{Direct Arylsulfonyl Fluoride Synthesis Reactions}

The direct formation of the $\mathrm{C}-\mathrm{SO}_{2} \mathrm{~F}$ bond constitutes the most elegant approach. Indeed, it allows straightforward access to arylsulfonyl fluorides, which constitutes an attractive option in late-stage functionalization. For this purpose, several research groups recently developed different strategies to address this challenge. Overviews of the most efficient methods are summarized herein.

\subsection{Sulfonyl Fluorides Synthesis from Aryl Halides}

The first example for the synthesis of arylulfonyl fluorides was reported by the groups of Willis and Bagley. The developed methodology is a one-pot two-step procedure in which sulfinates are in-situ formed through cross coupling between aryl bromide derivatives and DABSO (1,4-diazabicyclo [2.2.2] octane bis(sulfur dioxide) adduct) [29]. The commercially available $\mathrm{PdCl}_{2}$ (AmPhos) 2 (AmPhos: di-tert-butyl(4-dimethylaminophenyl)phosphine) was used as the active catalyst $(5 \mathrm{~mol} \%)$ and the reactions were performed in the presence of $\mathrm{Et}_{3} \mathrm{~N}$ as the base in $i \mathrm{PrOH}$ at $75^{\circ} \mathrm{C}$ for $24 \mathrm{~h}$. Afterwards, treatment of the reaction media with 1.5 equivalent of NFSI ( $N$-Fluorobenzenesulfonimide) led to the desired sulfonyl fluoride (Scheme 2a). It is worth noting that the reaction conditions tolerate the presence of several functional groups, and a wide variety of electron-donating and electronwithdrawing starting aryl bromides were converted to the desired products in good to excellent yields.

Furthermore, the authors turned their attention to the study of the reactions starting with heterocyclic compounds. Unfortunately, only very low yields were observed when the previous conditions were applied. In order to foster the reaction outcome, the authors demonstrated that upon microwave irradiation at $110^{\circ} \mathrm{C}$ and by using $N, N$ Dicyclohexylmethylamine $\left(\mathrm{Cy}_{2} \mathrm{NMe}\right)$ as the base, the conversion of several bromopyridine derivatives was achieved in moderate to very good yields. The authors assume that the steric hindrance of the base plays a key role in decreasing the homocoupling process of the starting aryl bromide as well as the rapid generation of the active palladium (0) catalyst (Scheme 2b).

It should be noted that a palladium-free procedure was also disclosed by using Grignard reagents in conjunction with DABSO in THF at room temperature. In that case, sulfinates were also formed as intermediates and the corresponding arylesulfonyl fluorides were obtained in very good to excellent yields upon treatment with NFSI (Scheme 2c).

In order to further demonstrate the versatility of the developed methodology, the authors proved its applicability to N-Boc-L-4-halophenylalanine methyl to generate the sulfonyl fluoride analogue 4 with good yields, starting from both bromide and iodide substrate (Scheme 3a). Next, aryl sulfonyl fluoride 4 reacts with the N-Boc-L-lysine methyl ester to form the sulfonamide 5 . Along the same lines, the halogenated tetramer 6 produced its corresponding sulfonyl fluoride 7 with good yield (Scheme $3 b$ ).

Shortly after, the group of Ball reported the synthesis of arylsulfonyl fluorides using aryl iodides as starting materials in conjunction with DABSO [30]. The reactions were carried out in the presence of $\mathrm{Pd}(\mathrm{OAc})_{2}(0.05$ equiv.)/CataCXium A (di-adamantylalkylphosphine or $\left.\mathrm{PAd}_{2} \mathrm{Bu}\right)\left(0.08\right.$ equiv.) as a precatalyst, $\mathrm{Et}_{3} \mathrm{~N}$, and $i \mathrm{PrOH}$ at $75^{\circ} \mathrm{C}$ for $16 \mathrm{~h}$. In this method, Selectfluor was used for the formation of the desired product from the sulfinate. Regarding the scope, aryl iodides bearing both electron-withdrawing and donating groups were converted smoothly to their corresponding aryl sulfonyl fluorides, producing products in good to excellent yields (Scheme 4). The authors also demonstrated that aryl sulfonyl fluorides react with several nucleophiles yielding the corresponding sulfones in very good to excellent yields. 
a)

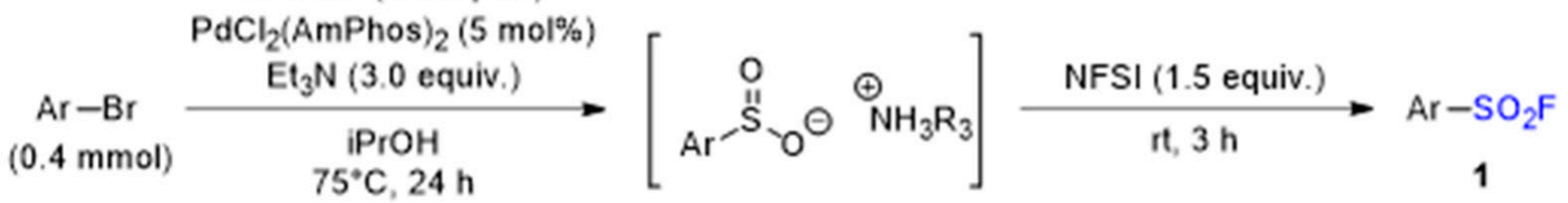

DABSO ( 0.6 equiv.)

Selected examples<smiles>O=S(=O)(F)c1ccccc1</smiles>

1a, $53 \%$<smiles>O=S(=O)(F)c1ccc(-c2ccccc2)cc1</smiles>

1b, $84 \%$<smiles>COc1ccc(S(=O)(=O)F)cc1</smiles>

1c, $66 \%$<smiles>CS(=O)(=O)c1ccc(S(=O)(=O)[O-])cc1</smiles>

1d, $82 \%$<smiles>CS(=O)(=O)c1ccc(S(=O)(=O)F)cc1</smiles>

1e, $76 \%$<smiles>COC(=O)c1cccc(S(=O)(=O)F)c1</smiles>

1f, $67 \%$

1g, $78 \%$

1h, $56 \%$

1i, $70 \%$

b)

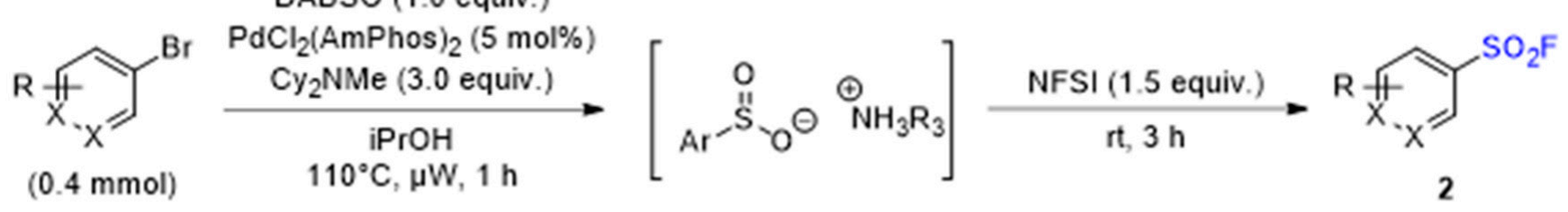

$\mathrm{X}=\mathrm{N}$ or $\mathrm{C}$

Selected examples<smiles>CC(=O)c1ccc(S(=O)(=O)F)cn1</smiles><smiles>N#Cc1ccc(S(=O)(=O)F)cn1</smiles>

2a, $53 \%$

2b, $32 \%$<smiles>O=S(=O)(F)c1cnc2occc2c1</smiles>

2c, $42 \%$
Boc<smiles>Cn1ncc2cc(S(=O)(=O)F)ccc21</smiles><smiles>O=S(=O)(F)c1ccnc(N2CCNCC2)c1</smiles>
Mé

2d, $51 \%$

2e, $46 \%$

c)

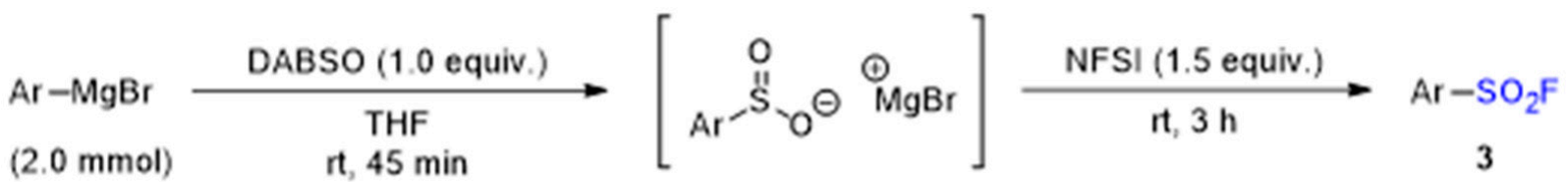

Selected examples<smiles>O=S(=O)(O)c1ccc(Cl)cc1</smiles>

$3 a, 72 \%$<smiles>O=S(=O)(F)c1ccc(F)cc1</smiles>

3b, $93 \%$<smiles>O=S(=O)(F)Cc1ccccc1</smiles>

3c $64 \%$<smiles>Cc1cccc(S(=O)(=O)F)c1</smiles>

$3 d, 73 \%$<smiles>O=S(=O)(O)c1cccs1</smiles>

$3 e, 78 \%$

Scheme 2. Sulfonyl fluorides synthesis from aryl bromide or Grignard reagents. 
a)

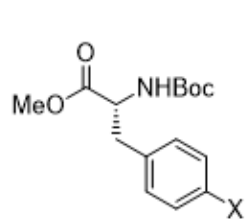

(0.4 mmol)

1) DABSO ( 0.6 equiv.)

$\mathrm{PdCl}_{2}$ (AmPhos) $)_{2}(5 \mathrm{~mol} \%)$

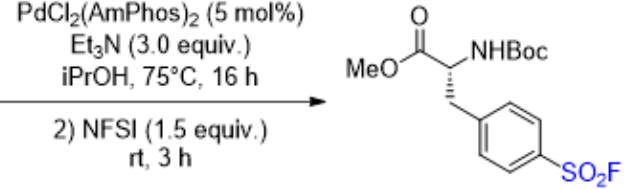

4

$\mathrm{X}=\mathrm{Br}, 61 \%$

$\mathrm{X}=\mathrm{I}, 73 \%$

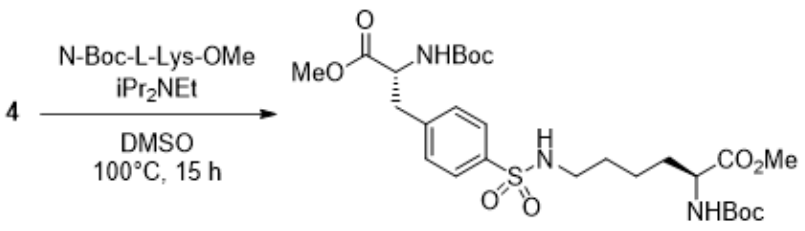

$5,84 \%$

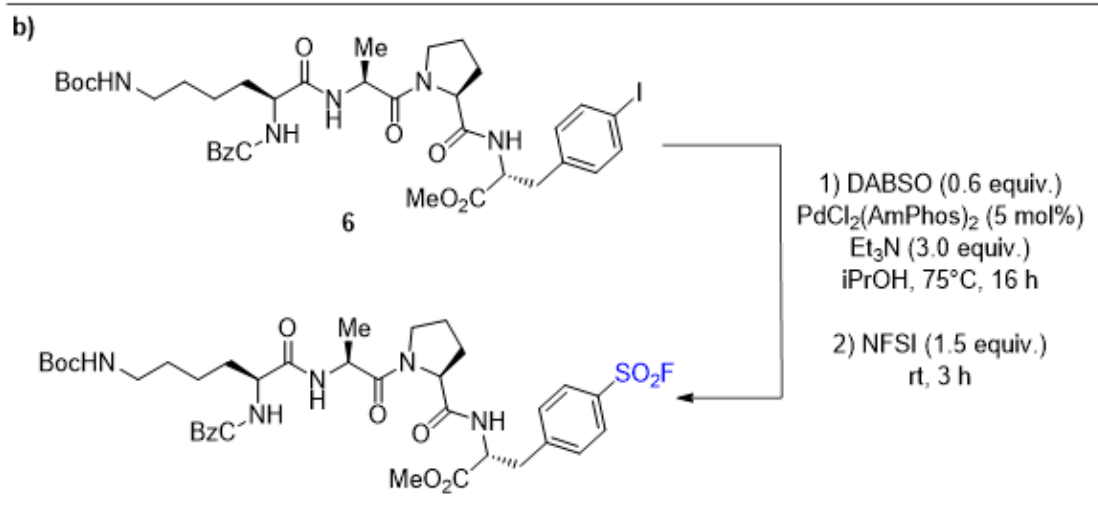

$7,65 \%$

Scheme 3. Synthesis of amino acid and peptidic sulfonyl fluorides.

$$
\begin{gathered}
\text { 1) } \left.\mathrm{Pd}(\mathrm{OAc})_{2}(0.05 \text { equiv. }) \text {, DABSO (1.2 equiv. }\right) \\
\mathrm{Et}_{3} \mathrm{~N}(3.0 \text { equiv. }), \mathrm{P}(\mathrm{Ad})_{2} \mathrm{Bu}(0.08 \text { equiv. }) \\
\text { iPrOH, } 75^{\circ} \mathrm{C}, 16 \mathrm{~h}
\end{gathered} \mathrm{Ar}-\mathrm{SO}_{2} \mathrm{~F}
$$

2) Selectfluor (2.0 equiv.) $\mathrm{MeCN}, 23^{\circ} \mathrm{C}, 2 \mathrm{~h} \quad 8$

Selected examples<smiles>CC(=O)c1ccc(S(=O)(=O)[O-])cc1</smiles>

$\mathbf{8 a}, 93 \%$<smiles>CC(=O)c1ccc(S(=O)(=O)F)cc1</smiles>

$\mathbf{8 b}, 67 \%$<smiles>O=S(=O)(F)c1ccc(Cl)cc1</smiles>

$8 c, 55 \%$<smiles>COc1ccc(S(=O)(=O)[O-])cc1</smiles>

$8 d, 45 \%$

8 e, $57 \%$

8f, $77 \%$

$8 g, 69 \%$<smiles>COc1cccc(S(=O)(=O)F)c1</smiles><smiles>COc1ccccc1S(=O)(=O)F</smiles><smiles>O=S(=O)(O)c1cccc2ccccc12</smiles><smiles>Cc1cc(C)cc(S(=O)(=O)F)c1</smiles>

8 h, $62 \%$

$8 \mathbf{i}, 45 \%$

8j, $72 \%$

8k, $59 \%$

Scheme 4. Pd-Catalyzed fluorosulfonylation of aryl iodides. 


\subsection{Sulfonyl Fluorides Synthesis from Arynes}

The use of sulfuryl fluoride $\mathrm{SO}_{2} \mathrm{~F}_{2}$ for the synthesis of aryl sulfonyl fluorides was reported by the group of Kim [31]. They performed a multicomponent reaction (MCR) involving the in-situ generation of aryne precursors from (trimethylsilyl) phenyl trifluoromethanesulfonate, secondary amines and $\mathrm{SO}_{2} \mathrm{~F}_{2}$. This methodology allows the straightforward synthesis of 2-dialkyl-, 2-alkylaryl-, or 2-diarylamino-substituted arylesulfonyl fluoride derivatives.

Depending on the substituents of the secondary amines, different reaction temperatures were used as shown in (Scheme 5). For instance, high yields were obtained with alkylarylamines with a reaction temperature of $-10^{\circ} \mathrm{C}$ (Scheme 5a). The $o$-dialkylamino substituted benzenesulfonyl fluorides were obtained in good yields when reactions involving dialkylamines were conducted at room temperature $\left(25^{\circ} \mathrm{C}\right)(\mathrm{Scheme} 5 \mathrm{~b})$. Finally, reactions involving diarylamines were conducted at $-30{ }^{\circ} \mathrm{C}$ and reduced yields were obtained due to the decreased activity at low temperatures (Scheme $5 \mathrm{c}$ ).

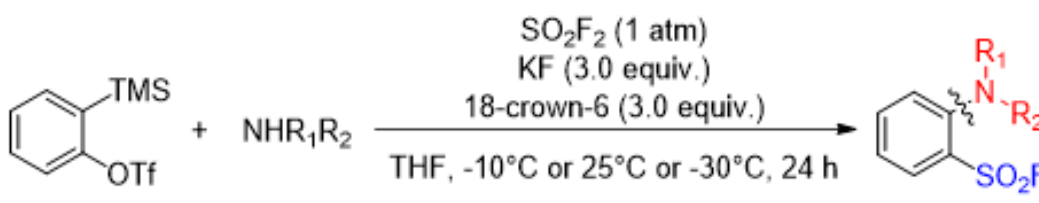

9<smiles>CCN(C)c1ccccc1</smiles>

Alkylarylamines

$9 a, 81 \%$

$9 b, 84 \%$<smiles>C=CCN(C)c1ccccc1</smiles><smiles>[Al]N(Cc1ccccc1)c1ccccc1</smiles><smiles>CN(C)c1ccccc1</smiles><smiles>CC(=O)c1ccc(N(C)C)cc1</smiles>

9c, $93 \%$

9d, $70 \%$

$$
9 \text { e, } 75 \%
$$

9f, $89 \%$<smiles>[R]c1ccc(N(C#N)C2CCCCC2)cc1</smiles>

gg, $77 \%$

9h, $90 \%$<smiles>CC(C)N(C(=O)O)C(C)C</smiles>

9 i, $82 \%$

b) Dialkylamines

$$
\mathrm{T}=25^{\circ} \mathrm{C}
$$<smiles>C=CCN(C)CC=C</smiles>

9j, $81 \%$

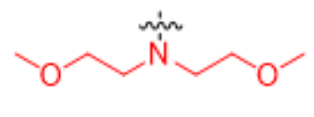

$9 k, 76 \%$<smiles>[Al]C(CN([Al])Cc1ccccc1)c1ccccc1</smiles>

9I, $75 \%$<smiles>O=C(O)COC(=O)N(c1ccccc1)c1ccccc1</smiles>

$9 m, 45 \%$

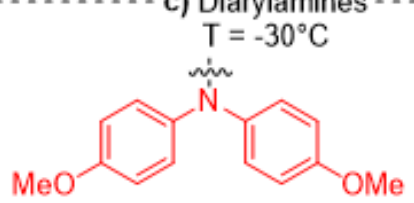

9 n, $41 \%$<smiles>N#Cc1ccc(Br)cc1</smiles>

$90,40 \%$

Scheme 5. Multi-component fluorosulfurylation of arynes.

The authors proposed the following mechanism (Scheme 6): upon the generation of the aryne $\mathbf{B}$ with the fluoride anion, a nucleophilic attack of the amine leads to the intermediate $\mathbf{C}$. The latter reacts with $\mathrm{SO}_{2} \mathrm{~F}_{2}$ via hydrogen bonding with the ammonium intermediate (enhancing the electrophilic character of $\mathrm{SO}_{2} \mathrm{~F}_{2}$ ) to finally produce the desired product $\mathbf{E}$ after the loss of HF. 


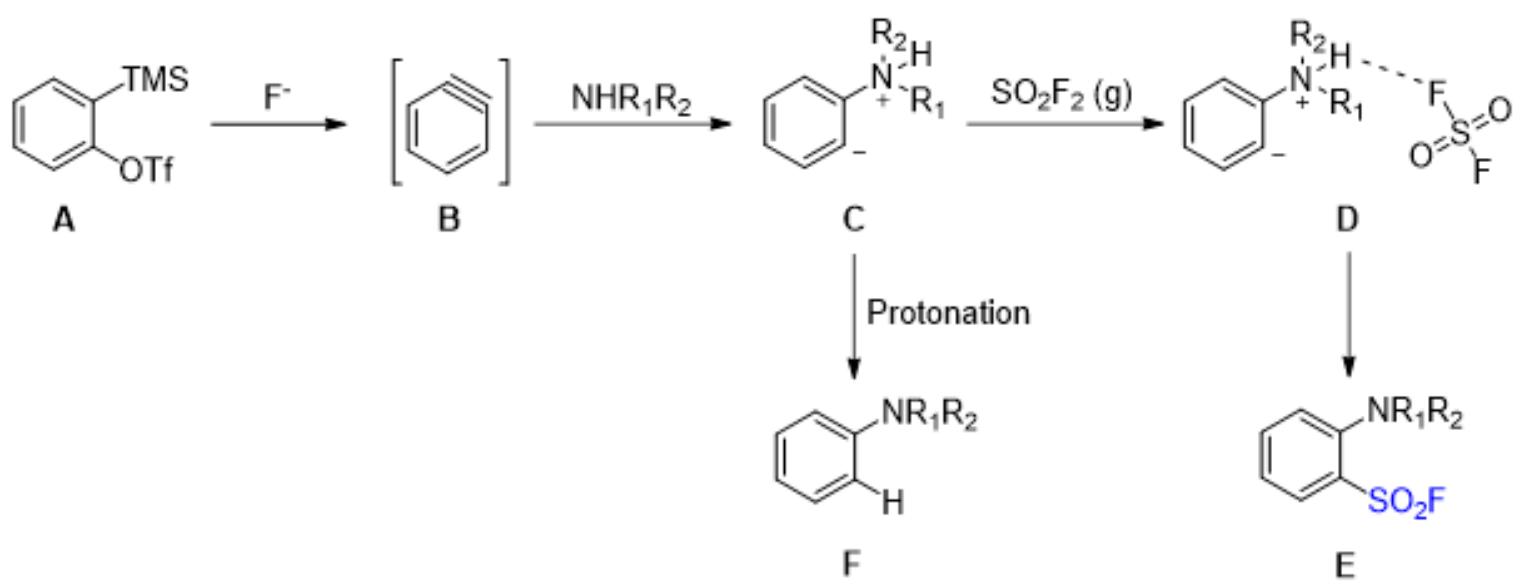

Scheme 6. Proposed mechanism for the multi-component fluorosulfurylation of arynes.

\subsection{Sulfonyl Fluorides Synthesis from Grignard Reagents}

By also using $\mathrm{SO}_{2} \mathrm{~F}_{2}$, the groups of Sammis and Ball disclosed a new method for the direct synthesis of sulfonyl fluorides by making use of alkyl, aryl and heteroaryl Grignard reagents [32]. The reactions were performed in THF at room temperature and the desired compounds were obtained in moderate to good yields.

Regarding the scope of the fluorosulfurylation of substituted phenylmagnesium bromide reagents, substrates bearing halogen, including para- $\mathrm{F}$ or $\mathrm{Cl}$, were effective in moderate to very good yields. Aryl magnesium bromides substituted with electron-donating groups were smoothly converted to the desired products, $\mathbf{1 0 d}$ and $\mathbf{1 0 f}-\mathbf{1 0 h}$. The arylmagnesium bromide, substituted with two trifluoromethyl substituents 10i, is sluggish toward the transformation.

The authors have also proved that this protocol encompasses heteroaryl sulfonyl fluoride derivatives (Scheme $7 \mathrm{~b}$ ). Indeed, thiophene and thiazole, as well as pyridine derivatives, were converted to their corresponding products with moderate to good reaction outcomes.

\subsection{Sulfonyl Fluorides Synthesis from Aryldiazonium Salts}

Recently, the group of Liu and Chen disclosed a new copper-based method for converting a large series of aryldiazonium salts to arylsulfonyl fluorides in the presence of DABSO and $\mathrm{KHF}_{2}$ [33].

The reactions were carried out in $\mathrm{MeCN}$ in the presence of catalytic amounts of $\mathrm{CuCl}_{2}$ (20 mol\%) and 6,6'-dimethyl-2,2'-dipyridyl (dmbp) (20 mol\%) at room temperature. Aryldiazonium salts were converted to the desired arylsulfonyl fluoride analogues in good yields. Both electron rich and electron poor arenes were converted in moderate to good yields. Furthermore, quite a large number of functionalities were tolerated under the reaction conditions. Indeed, aryldiazonium salts bearing amide $\mathbf{1 2 e}$, ester $\mathbf{1 2} \mathbf{f}$ and ketone $\mathbf{1 2} \mathbf{i}$, as well as cyano $\mathbf{1 2} \mathbf{j}$ groups, were smoothly converted to their corresponding arylsulfonyl fluoride products. Additionally, the authors demonstrated that various heteroaryldiazonium salts could also be used under the reaction conditions (Scheme 8).

To further demonstrate the versatility of the methodology, product $\mathbf{1 2 b}$ was synthesized on the gram scale with a good reaction outcome.

The authors proposed two plausible mechanisms. On the one hand, aryldiazonium salt $\mathbf{A}$ easily generates the aryl radical through reduction by $\mathrm{Cu}(\mathrm{I})$ species via a single electron transfer (SET) process. The aryl radical is quickly trapped by $\mathrm{SO}_{2}$ to produce the resulting relatively stabilized arylsulfonyl radical $\left[\mathrm{ArSO}_{2}{ }^{\bullet}\right]$. Afterwards, a Sandmeyer-type reaction occurs by transferring a chloride to the arylsulfonyl radical to form $\mathrm{ArSO}_{2} \mathrm{Cl}$ and regenerates the $\mathrm{Cu}(\mathrm{I})$. Finally, a fluorine/chlorine exchange takes place to generate the desired product B (Scheme 9, path A). 
a)

$$
\begin{aligned}
& \underset{(1.0 \text { equiv. })}{\stackrel{\mathrm{R}-\mathrm{MgX}}{\stackrel{\mathrm{SO}_{2} \mathrm{~F}_{2}(4.6 \text { equiv. })}{\mathrm{THF}} 23^{\circ} \mathrm{C}, 1 \mathrm{~h}}} \stackrel{\mathrm{R}-\mathrm{SO}_{2} \mathrm{~F}}{\mathbf{1 0}} \\
& \mathrm{X}=\mathrm{Br} \text { or } \mathrm{Cl}
\end{aligned}
$$

Selected examples<smiles>O=S(=O)(O)c1ccccc1</smiles><smiles>[X]c1ccc(S(=O)(=O)OF)cc1</smiles>

$\mathrm{X}=\mathrm{F}, 10 \mathrm{~b}, 78 \%$ $\mathrm{X}=\mathrm{Cl}, 10 \mathrm{c}, 59 \%$<smiles>CCc1cc(C)cc(C)c1S(=O)(=O)F</smiles>

10 h, $52 \%$<smiles>[R]c1ccc(S(=O)(=O)F)cc1</smiles>

$R=$ Me, 10d $56 \% \quad X=0,10 f, 68 \%$ $\mathrm{R}=\mathrm{Ph}, 10 \mathrm{e}, 64 \% \quad \mathrm{X}=\mathrm{S}, 10 \mathrm{~g}, 64 \%$<smiles>O=S(=O)(F)c1cc(C(F)(F)F)cc(C(F)(F)F)c1</smiles>

10i, $18 \%$

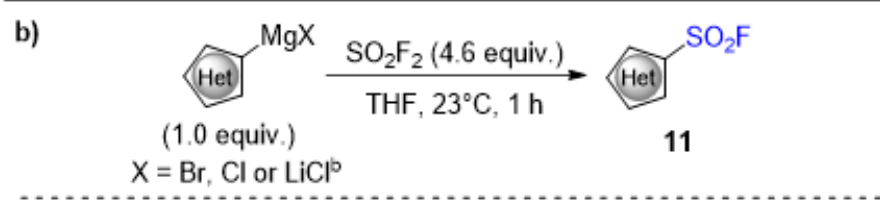

Selected examples<smiles>O=S(=O)(OF)c1cccs1</smiles>

11a, $59 \%$<smiles>O=S(=O)(F)c1cccnc1</smiles>

11d, $44 \%$

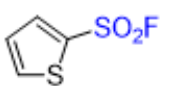

11b, $61 \%$<smiles>O=S(=O)(F)c1ccc(Cl)s1</smiles>

$11 \mathrm{e}, 48 \%$<smiles>O=S(=O)(OF)c1cccs1</smiles>

11c, $57 \%$

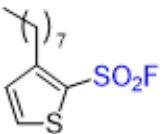

11f, $32 \%$

Scheme 7. Fluorosulfurylation using various Grignard reagents.

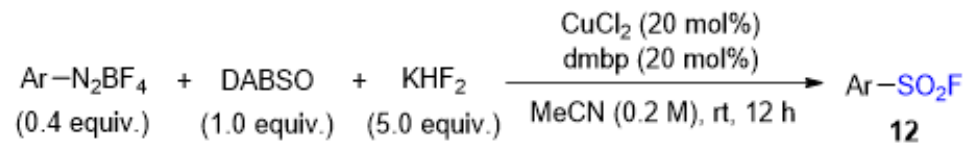

Selected examples
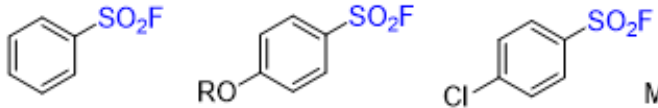<smiles>CC(=O)Nc1ccc(S(=O)(=O)[O-])cc1</smiles>

12a, $57 \%$

$\mathrm{R}=\mathrm{Me}, 12 \mathrm{~b}, 66 \%$ $\mathrm{R}=\mathrm{Ph}, 12 \mathrm{c}, 56 \%$

12d, $49 \%$

$12 \mathrm{e}, 68 \%$<smiles>COC(=O)c1cc(C(C)=O)cc(S(=O)(=O)F)c1</smiles>

12f, $45 \%$<smiles>CC(=O)c1cncc(S(=O)(=O)O)c1</smiles>

12g. $41 \%$<smiles>COC(=O)c1sccc1S(=O)(=O)F</smiles>

$12 \mathrm{~h}, 41 \%$<smiles>CC(=O)c1ccc(S(=O)(=O)F)cc1</smiles>

12i, $61 \%$<smiles>[R]c1ccc(S(=O)(=O)F)cc1</smiles>

$\mathrm{R}=\mathrm{CN}, 12 \mathrm{j}, 65 \%$ $\mathrm{R}=\mathrm{C}(\mathrm{Ph})_{3}, 12 \mathrm{k}, 53 \%$<smiles>Cc1cc(C)nc(NS(=O)(=O)c2ccc(S(=O)(=O)O)cc2)n1</smiles>

$12 \mathrm{I}, 48 \%$

Scheme 8. Synthesis of arylsulfonyl fluorides via copper-catalyzed fluorosulfonylation of various aryldiazonium salts. 
Path A

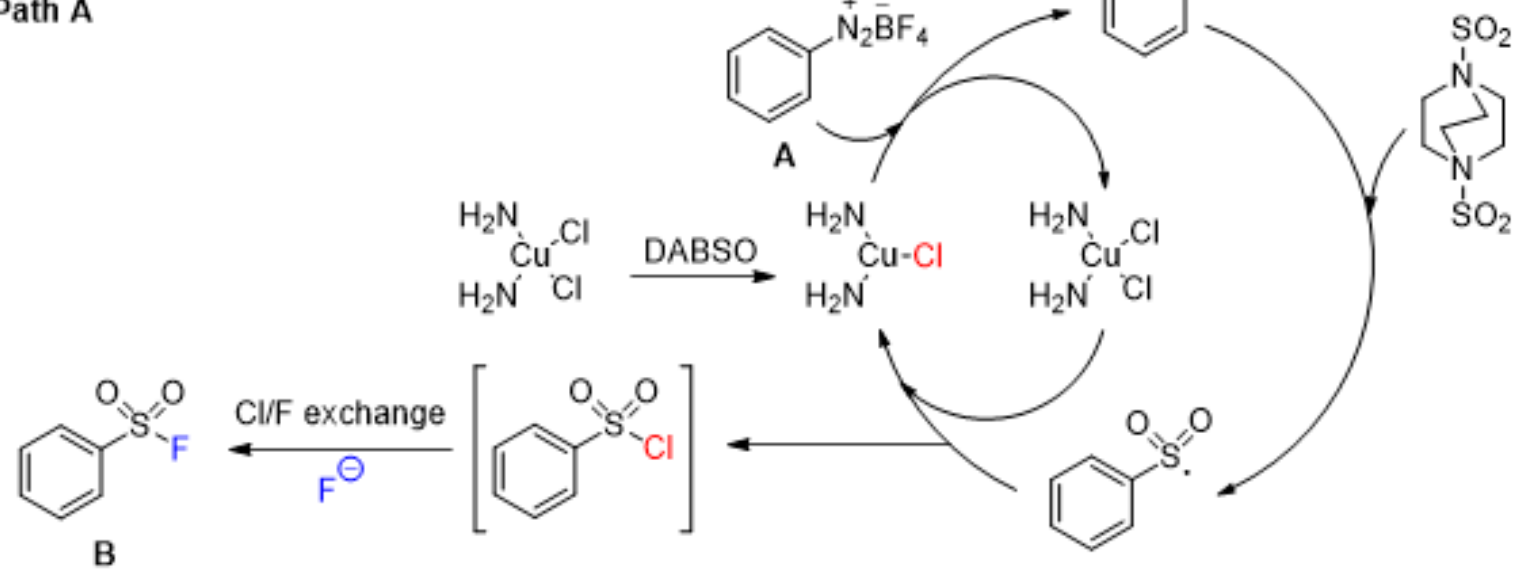

Path B

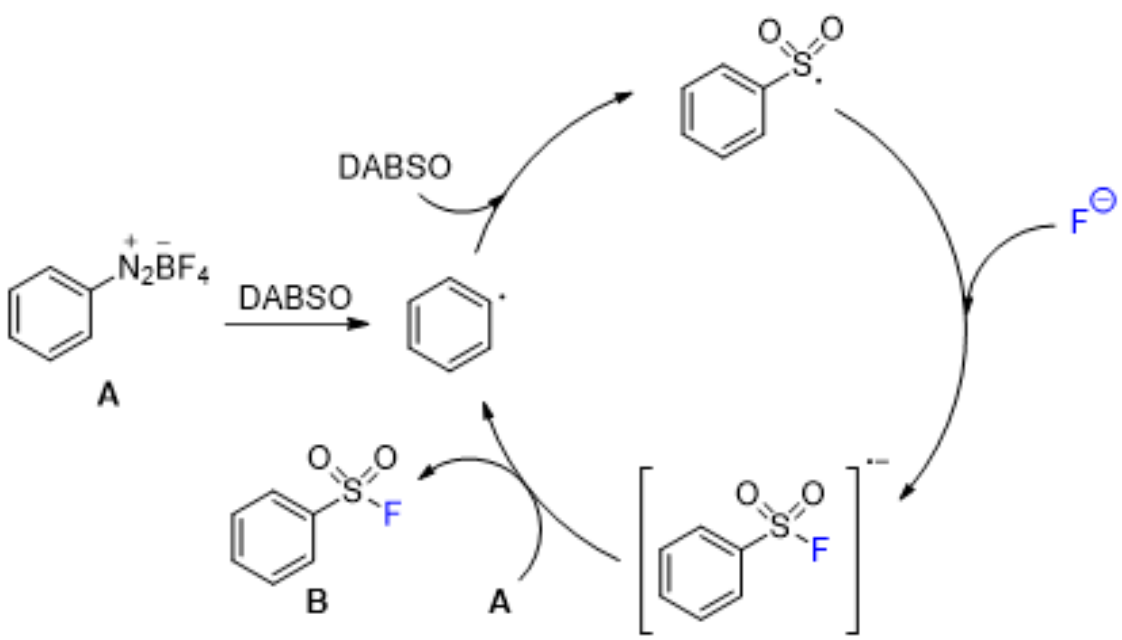

Scheme 9. Proposed mechanism for the synthesis of arylesulfonyl fluorides via copper-catalyzed fluorosulfonylation of aryldiazonium.

On the other hand, aryldiazonium salt $\mathbf{A}$ easily generates the aryl radical through activation with DABSO and is quickly trapped by $\mathrm{SO}_{2}$ under the reaction conditions to produce the resulting relatively stabilized arylsulfonyl radical [ArSO $\left.2^{\bullet}\right]$, which can combine with the fluorine anion offered by $\mathrm{KHF}_{2}$ to give the radical anion $\left[\mathrm{ArSO}_{2} \mathrm{~F}^{-\bullet}\right]$. The radical anion could be responsible for the reduction of the aryldiazonium salt $\mathbf{A}$ through SET, generating a new aryl radical and the desired product B (Scheme 9, path B).

More recently, Weng and co-workers reported a copper-free fluorosulfonylation of aryldiazonium salts using sodium metabisulfite as the source of sulfur dioxide and Selectfluor as the fluorinating agent [34]. The reaction was performed in $\mathrm{MeOH}$ at $70{ }^{\circ} \mathrm{C}$. The aryldiazonium tetrafluoroborates bearing either electron-donating or withdrawing groups were obtained with good yields. Interestingly, this protocol was applied to diazonium salts derived from a neratinib (anticancer) intermediate, producing the corresponding sulfonyl fluorides 13k in a synthetically useful yield. Radical scavenger and radical clock experiment suggested the formation of aryl radical in this transformation as a key intermediate (Scheme 10). The latter reacts with sodium metabisulfite to form the sulfonyl radical. The desired compound is formed after reaction with Selectfluor. 


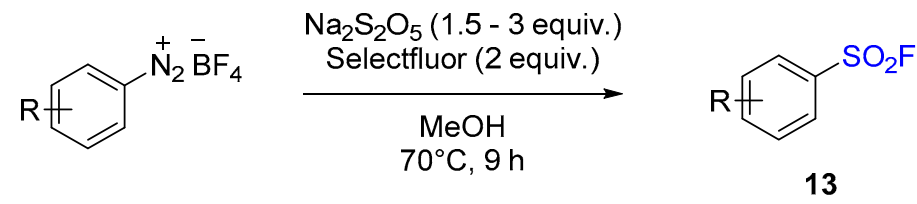<smiles>Cc1ccc(S(=O)(=O)[O-])cc1</smiles>

$13 a, 66 \%$<smiles>CC(C)(C)c1ccc(S(=O)(=O)F)cc1</smiles>

13b, $70 \%$<smiles>O=S(=O)(F)c1ccc(Br)cc1</smiles>

$13 c, 63 \%$<smiles>O=S(=O)(F)c1ccccc1Br</smiles>

13d, $52 \%$<smiles>O=[N+]([O-])c1ccc(S(=O)(=O)F)cc1</smiles>

$13 e, 60 \%$<smiles>COC(=O)Nc1ccc(S(=O)(=O)F)cc1</smiles>

13f, $51 \%$

13g, $77 \%$<smiles>O=C(O)c1ccc(S(=O)(=O)F)cc1</smiles><smiles>COc1ccc(S(=O)(=O)[O-])cn1</smiles>

$13 \mathbf{i}, 63 \%$<smiles>COC(=O)c1sccc1S(=O)(=O)OF</smiles>

13j, 35\%<smiles>O=S(=O)(F)c1ccc(OCc2ccccn2)c(Cl)c1</smiles>

13k, $53 \%$

\section{Proposed mechanism}

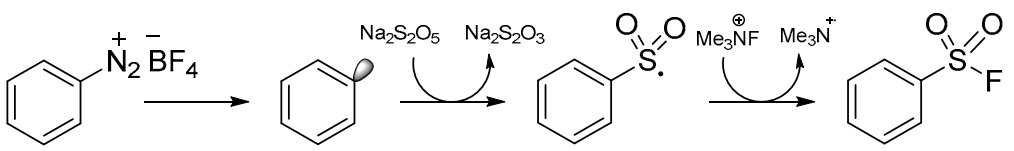

Scheme 10. Fluorosulfonylation of aryldiazonium salts.

A step further; the direct use of commercially available anilines as starting materials for the synthesis of arylsulfonyl fluorides has also been undertaken. The authors demonstrated that a one-pot two-step procedure could take place for the generation of the diazonium salt followed by the synthesis of the desired product with a moderate reaction outcome (Scheme 11).

Aqueous $\mathrm{HBF}_{4} 50 \%$

(2 equiv.)<smiles></smiles>

\section{$t$-BuONO (2 equiv.)}

$\mathrm{EtOH}$

$0^{\circ} \mathrm{C}, 1 \mathrm{~h}$

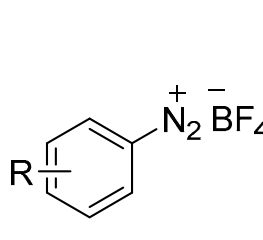

$\mathrm{Na}_{2} \mathrm{~S}_{2} \mathrm{O}_{5}$

(1.5 - 3 equiv.)

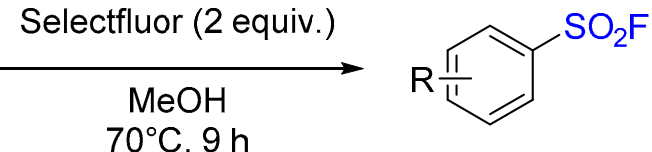

$70^{\circ} \mathrm{C}, 9 \mathrm{~h}$

14a, $\mathrm{R}=p-\mathrm{Me} 60 \%$

14b, $\mathrm{R}=p-\mathrm{NO}_{2} 56 \%$

Scheme 11. One-pot synthesis of sulfonyl fluorides from anilines.

Very recently, we demonstrated that aryl sulfonyl fluorides could be obtained under visible-light metal-free procedures by using cyanoarenes as organophotocatalysts [35-40]. Indeed, the association of diazonium salts with DABSO in the presence or not of an external fluoride source $\left(\mathrm{KHF}_{2}\right)$ allows access to a wide variety of arylsulfonyl fluorides with moderate to very good yields (Scheme 12). The reactions were performed in MeCN as a solvent at room temperature under blue LED irradiation. Both electron withdrawing and electron donating groups were tolerated under the reaction conditions $(\mathbf{1 5 a}-\mathbf{1 5} \mathbf{d}$ and 15i-151). Interestingly, the reaction in the presence of halogen substituents gave the desired products in synthetically useful yields $(\mathbf{1 5 e}-\mathbf{1 5 h})$. To some extent, heterocyclic 
compounds $15 \mathrm{~m}$ and $15 \mathrm{n}$ were also tolerated under this protocol. More interestingly, the complex molecular structure of the estrone derivative 150 was smoothly converted to the corresponding arylsulfonyl fluoride.

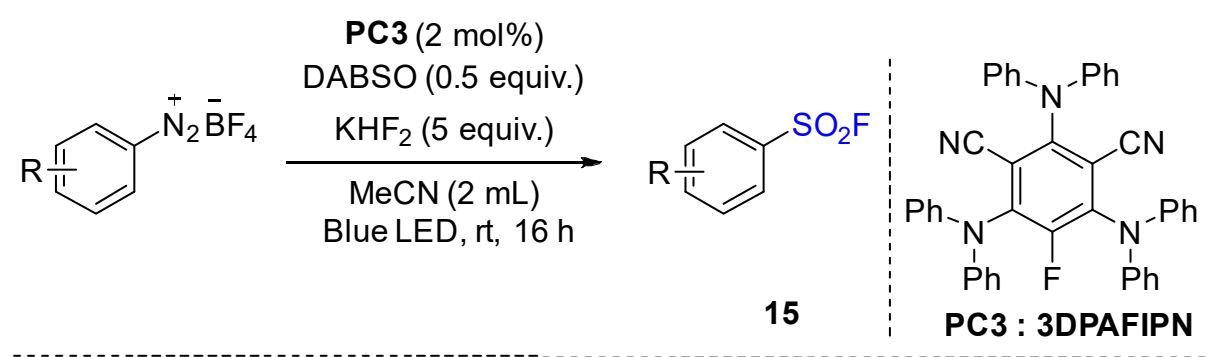<smiles>Cc1ccc(S(=O)(=O)O[Na])cc1</smiles>

$15 a, 59 \%(70 \%)$<smiles>COc1ccccc1S(=O)(=O)F</smiles>

15b, $69 \%(80 \%)$<smiles>O=S(=O)(O)c1ccc(Cl)cc1</smiles>

$15 f, 39 \%(49 \%)$<smiles>COc1ccc(S(=O)(=O)[O-])cc1</smiles>

$15 \mathrm{c}, 60 \%(72 \%)$<smiles>O=S(=O)(OF)c1ccccc1</smiles>

$15 d, 55 \%(64 \%)$<smiles>O=S(=O)(F)c1ccc(Br)cc1</smiles>

$15 g, 38 \%(47 \%)$<smiles>O=S(=O)(O)c1ccc(I)cc1</smiles>

$15 \mathrm{~h}, 36 \%(45 \%)$<smiles>N#Cc1ccccc1S(=O)(=O)F</smiles>

$15 \mathbf{k}, 38 \%(48 \%)$<smiles>O=S(=O)(F)c1ccc(C(F)(F)F)cc1</smiles>

15I, $54 \%(76 \%)$<smiles>COC(=O)c1sccc1S(=O)(=O)OC</smiles>

$15 \mathrm{~m},(40 \%)$<smiles>O=S(=O)(OF)c1cnc2ccccc2c1</smiles>

$15 n, 31 \%(42 \%)$<smiles>CC12CCC3c4ccc(OC(=O)c5ccc(S(=O)(=O)F)cc5)cc4CCC3(C1)C1CCC(=O)[C@@]12C</smiles>

$150,42 \%(50 \%)$

Scheme 12. Visible-light synthesis of arysulfonyl fluorides.

In order to shed the light on the mechanism, several techniques were combined. Luminescence quenching allows the confirmation of the reduction of the diazonium salt. Quantum yield measurement allows the confirmation of the stepwise nature of the mechanism. Moreover, EPR spectroscopy confirmed the formation of aryl radical formed through single electron transfer from the exited photocatalyst to the diazonium salt, and the corresponding adduct was obtained with $N$-tert-butyl- $\alpha$-phenylnitrone $(\mathrm{PBN})$ as a radical trapping agent. Performing the same reaction with DABSO also allows the confirmation of the presence of the $\mathrm{ArSO}_{2}$ radical and this adduct was also observed with PBN. Finally, density functional theory (DFT) calculations allow us to confirm the presence of a sulfonium intermediate formed through radical-radical coupling between $\mathrm{ArSO}_{2}$ radical and $\mathrm{DABCO}^{+}$generated through the reduction of $\mathrm{PC}^{+}$to regenerate the catalyst at its ground state (Scheme 13). 


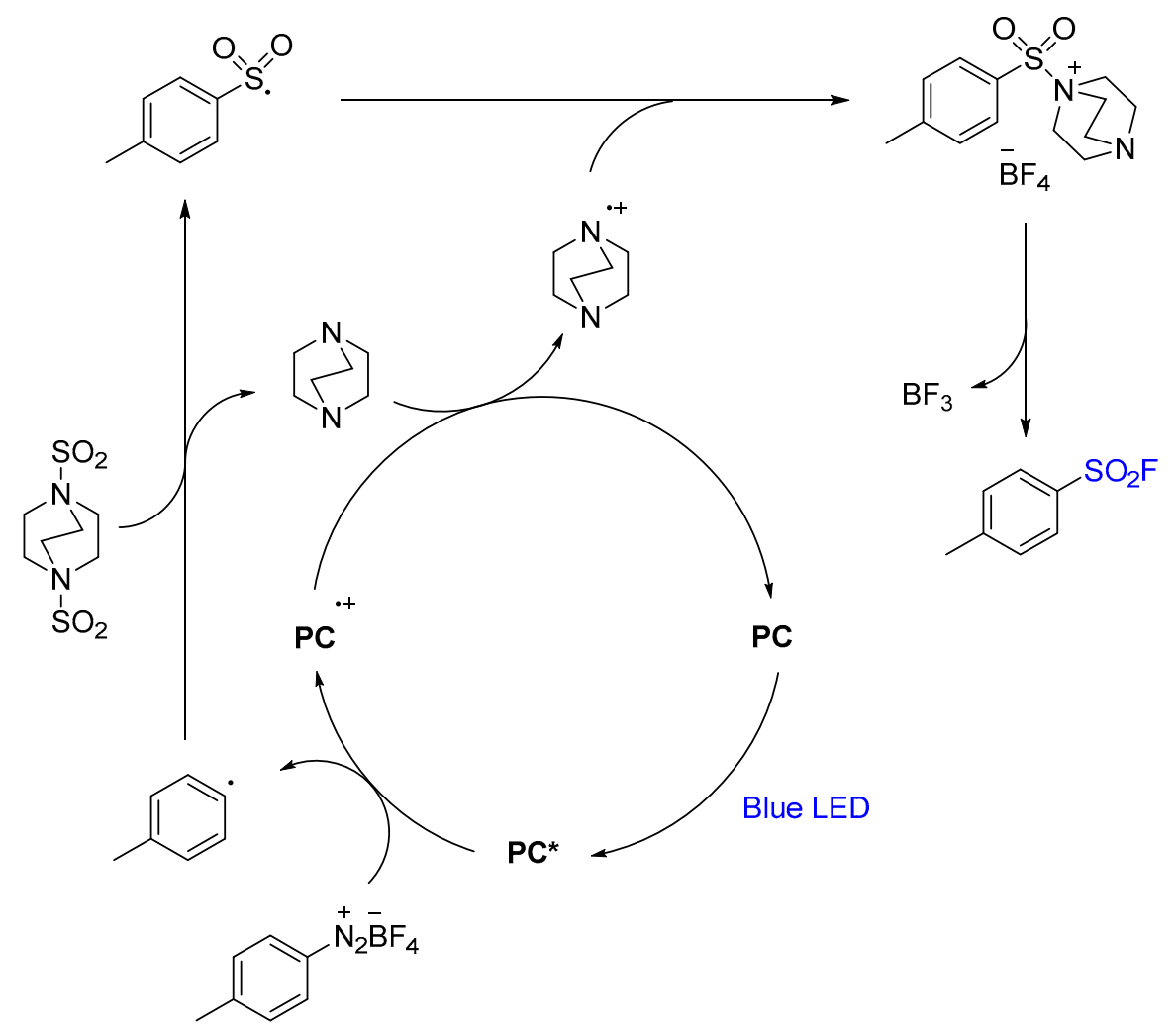

Scheme 13. Proposed mechanism for the visible-light synthesis of arysulfonyl fluorides.

\section{Indirect Arylesulfonyl Fluoride Synthesis Reactions}

In addition to direct synthetic strategies, indirect methodologies are an alternative for the synthesis of arylsulfonyl fluorides and are well described in the literature. They actually complete the toolbox, offering a variety of retrosynthetic options to access the desired compounds. Herein, indirect methodologies are outlined.

\subsection{Sulfonyl Fluorides Synthesis from Arylsulfonyl Chlorides}

The best known methodology makes use of arylsulfonyl chlorides as the starting materials [17,41,42]. In 1977, Bianchi and co-workers reported an easy and simple method for the synthesis of sulfonyl fluorides using 18 -crown-6 ether and potassium fluoride. The reaction takes place at room temperature in the presence of the 18-crown-6 ether catalyst, sulfonyl chlorides and an excess of potassium fluoride in acetonitrile. Sulfonyl chlorides undergo fluorine substitution with excellent reaction outcomes (Scheme 14).
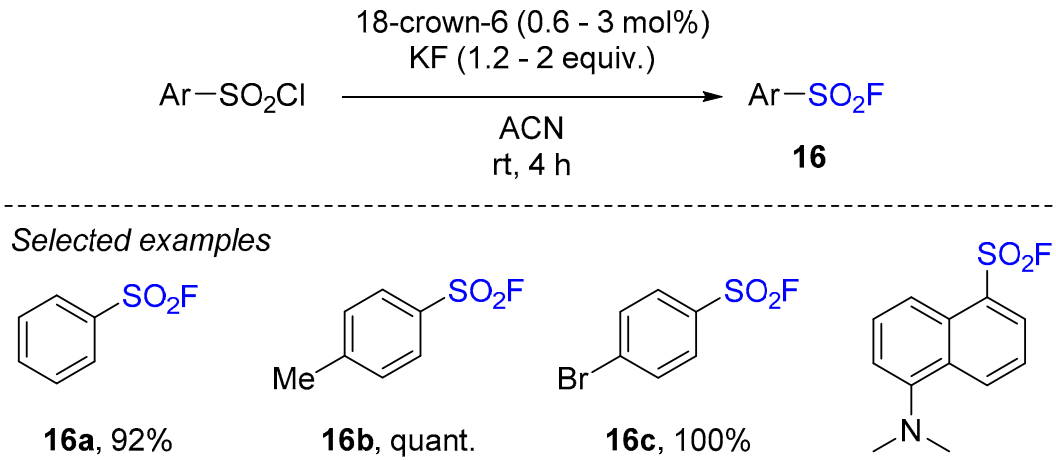

$16 d, 100 \%$

Scheme 14. Conversion of sulfonyl chlorides to sulfonyl fluorides. 
Sharpless and co-workers also used sulfonyl chlorides as starting materials for the formation of sulfonyl fluorides derivatives [17]. The reactions were carried out in the presence of saturated aqueous solution of KFHF in acetonitrile, which produces a biphasic mixture (THF or $\mathrm{CH}_{2} \mathrm{Cl}_{2}$ ) at room temperature.

A wide variety of electron-donating and electron-withdrawing functional groups gave the desired products in excellent yields. A large functional group tolerance was also observed, including carboxylic acid $17 \mathrm{e}$, nitro $17 \mathrm{~b}$ and cyano $17 \mathrm{c}$ groups. The presence of an unsaturated alkene is also tolerated $\mathbf{1 7 f}$ (Scheme 15).

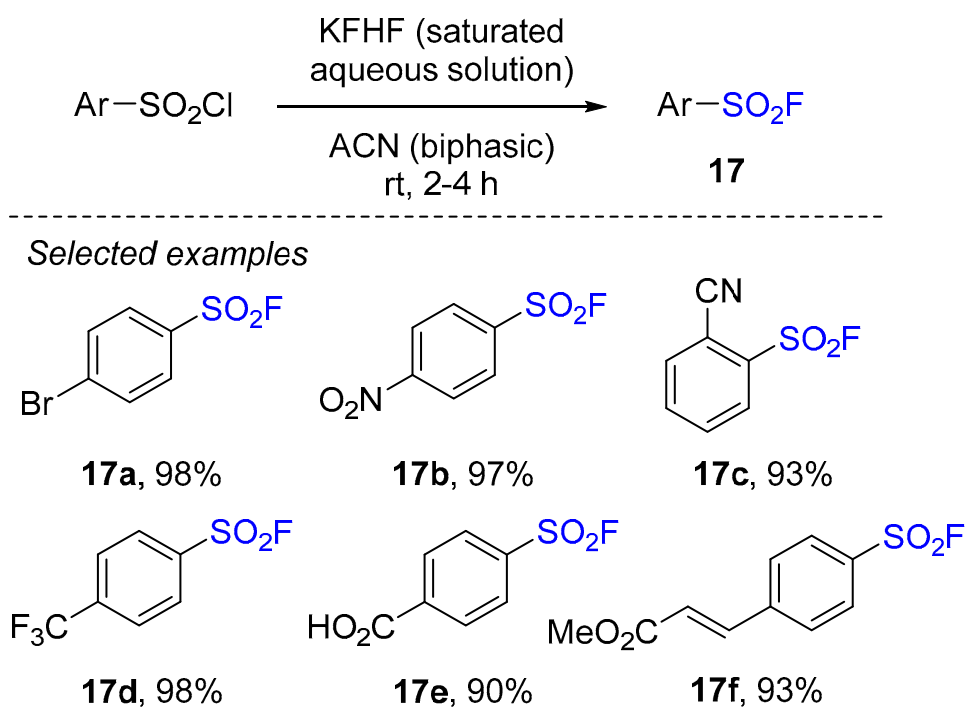

Scheme 15. Sulfonyl fluorides synthesis from sulfonyl chlorides.

\subsection{Sulfonyl Fluorides Synthesis from Sulfonyl Hydrazides and Sodium Arylsulfinates}

Tang and Wang have developed a simple and effective fluorination method using sulfonyl hydrazide in water without additives or catalysts to obtain sulfonyl fluorides in good to excellent yields [43]. Selecfluor was used as a fluorinating agent and the reactions were performed in water at $60{ }^{\circ} \mathrm{C}$.

The reaction scope encompasses a large panel of starting materials including electrondonating and electron-withdrawing substituents with moderate to excellent reaction outcomes. Aliphatic substrates were also effective under the reaction conditions. The reaction was also scaled-up, $1.86 \mathrm{~g}$ of compound 18a was obtained in $88 \%$ yield (Scheme 16).

Furthermore, the authors have shown that the use of sodium arylsulfinates as starting materials under the same reaction conditions is also effective for the formation of arylesulfonyl fluorides with similar yields to those obtained with sulfonyl hydrazides (Scheme 16).

The radical inhibitor (2,2,6,6-Tetramethylpiperidin-1-yl)oxyl (TEMPO) inhibits the reaction, thus favoring a radical mechanism (Scheme 16).

\subsection{Sulfonyl Fluorides Synthesis from Thiols and Disulfides}

Hallstrom and Wright reported a new method using heteroaromatic thiols as a starting material for the synthesis of heteroaromatic sulfonyl fluorides [44]. Heteroaromatic thiols are oxidized with aqueous sodium hypochlorite to obtain the corresponding sulfonyl chlorides, then $\mathrm{KHF}_{2}$ is added to perform a $\mathrm{Cl}-\mathrm{F}$ exchange, forming the sulfonyl fluoride products.

The authors have shown that a wide variety of heteroaromatic thiols, even in the presence of electron-donating groups, are tolerated under these conditions, including pyrimidine 19a and 19c, pyridine 19b and pyridazine 19d (Scheme 17). 


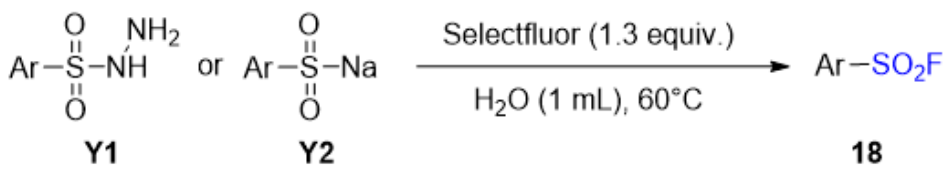

Selected examples<smiles>Cc1ccc(S(=O)(=O)O)cc1</smiles>

18a

(Y1, 94\%)

(Y2, 94\%)<smiles>CC(C)c1ccc(S(=O)(=O)O[Na])cc1</smiles>

$20 \mathrm{~b}$

(Y1, 91\%)

(Y2, 88\%)<smiles>COc1ccc(S(=O)(=O)O)cc1</smiles>

20c

(Y1, 87\%)<smiles>O=S(=O)(F)c1ccc(F)cc1</smiles>

(Y1, 81\%)

(Y2, 79\%)

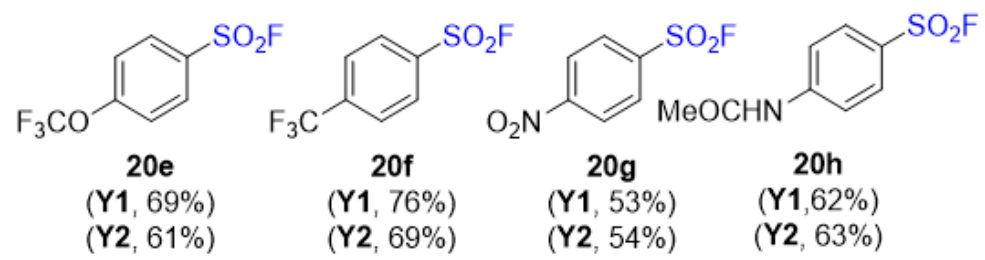<smiles>O=S(=O)(F)c1cccs1</smiles><smiles>Cc1cc(C)c(S(=O)(=O)O)c(C)c1</smiles><smiles>O=S(=O)(O)c1ccc2ccccc2c1</smiles>

\section{0i}

(Y1, 77\%)

(Y2, 76\%)

\section{0j}

(Y1, 82\%) 20k

(Y1, 96\%)

(Y2, 85\%)

Scheme 16. Synthesis of sulfonyl fluorides from sulfonyl hydrazides or sodium aryl sulfinates.

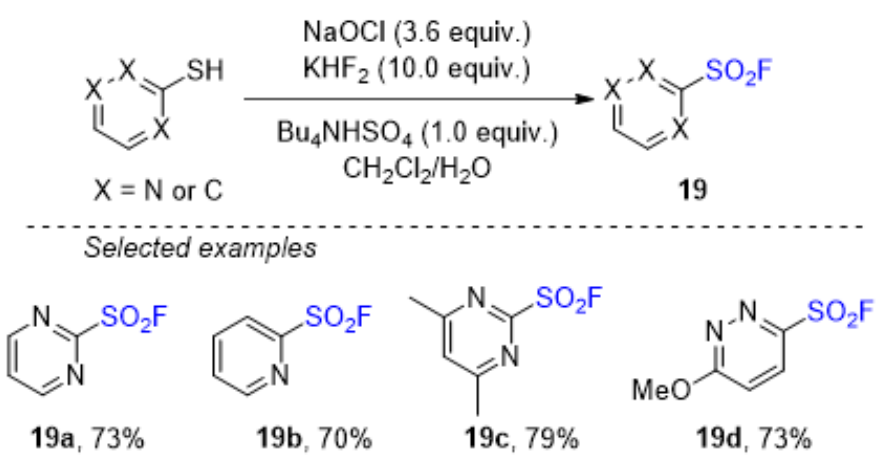

Scheme 17. Synthesis of heteroaryl sulfonyl fluorides from heteroaryl thiols.

Later, the group of Kirihara used disulfides as starting materials for the synthesis of arylsulfonyl fluorides. Selectfluor was used in high amounts (6.5 equiv.) as both the oxidant and the electrophilic source of fluorine [45].

The reaction was performed in a refluxed mixture of MeCN-water (10:1). This reaction tolerates the presence of electron-donating groups and the desired products were formed in good to excellent yields (20a-20d). In contrast, electron-withdrawing disulfides were not tolerated (Scheme 18).

Recently, the group of Noël disclosed an electrochemical approach for the synthesis of sulfonyl fluorides [46]. This method makes use of thiols or disulfides as starting materials, with KF (5.0 equiv.) as the source of fluorine and supports electrolyte and pyridine (1.0 equiv.) at room temperature in a mixture of $\mathrm{MeCN} / \mathrm{HCl}$ aq (1:1). The reagents were introduced into an undivided cell with a graphite anode and a stainless-steel cathode. The current was set at $20 \mathrm{~mA}$, or constant voltage (3.2 V). 


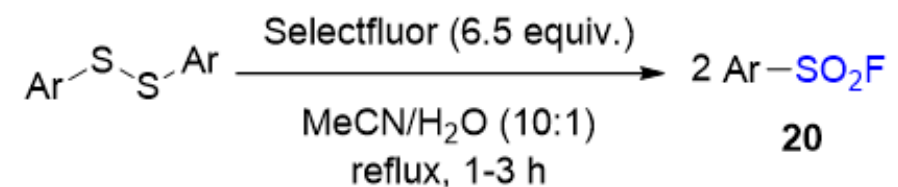

Selected examples

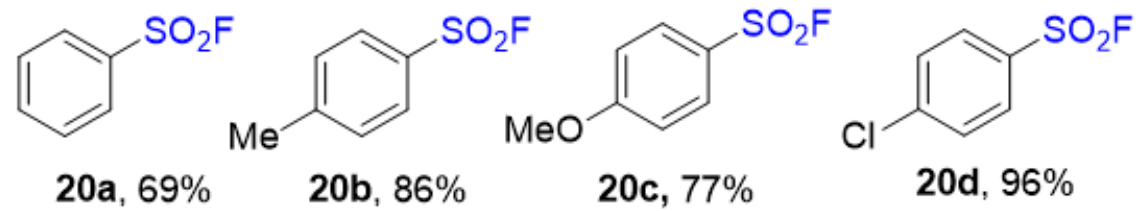

Scheme 18. Synthesis of sulfonyl fluorides from disulfides.

This electrochemical method tolerates substrates with electron-donating and withdrawing groups $\mathbf{2 1 a} \mathbf{- 2 1} \mathbf{g}$ and halogen $\mathbf{2 1} \mathbf{h}-\mathbf{2 1} \mathbf{i}$, as well as protected amines $\mathbf{2 1 j}$. The desired compounds were obtained with moderate to excellent reaction outcomes. Furthermore, heterocyclic thiols were also successfully applied 21k-211 (Scheme 19).

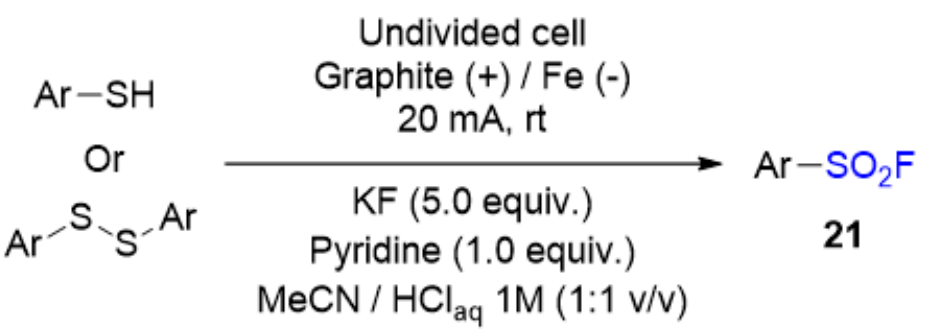<smiles>O=S(=O)(F)c1ccccc1</smiles>

21a, $85 \%$<smiles>[X]c1ccc(S(=O)(=O)F)cc1</smiles>

21g, $X=F, 61 \%$

21h, $X=\mathrm{Cl}, 62 \%$ 21i, $X=B r, 58 \%$<smiles>Cc1ccc(S(=O)(=O)O)cc1</smiles>

21b, ortho, $87 \%$ 21c, meta, $68 \%$ 21d, para, $63 \%$<smiles>CCNc1ccc(S(=O)(=O)F)cc1</smiles>

21j, $19 \%$<smiles>COC(=O)c1ccccc1S(=O)(=O)F</smiles>

$21 e, 88 \%$<smiles>Cc1cc(C)nc(S(=O)(=O)F)n1</smiles>

21k, $74 \%$<smiles>O=S(=O)(F)c1ccc(C(F)(F)F)cc1</smiles>

21f, $61 \%$

Scheme 19. Synthesis of sulfonyl fluorides from thiols or disulfides.

Several versatile organic reactions were performed thanks to electrochemical transformations, which are known for their powerful mode of activation [47-49]. This electrochemical method allows the oxidization of thiols and disulfides without the addition of external oxidants, which makes this chemistry more in line with the current environmental concerns. Compared to conventional thermal methods, the parameters of the electrochemical approach can be easily adjusted $[47,50,51]$. This methodology is able to overcome certain challenges, allowing this transformation to take place. These challenges include the low solubility of potassium fluoride in organic solvents and the difficulty of forming the S-F bond by combining a nucleophilic fluorinated reagent with thiols [52-54]. Pyridine plays the role of both electron mediator and of a phase-transfer catalyst to transfer fluorine to the organic phase. 
Various experiments have been carried out to obtain information about the reaction mechanism. In particular, kinetic experiments have revealed a rapid conversion of thiols into disulfides, and the addition of radical scavengers confirms the presence of radical intermediates.

In the presence of hydrochloric acid and pyridine, the KF is transferred into the organic phase to react with the disulfides obtained from the oxidation of thiols through the single electron transfer (SET) process. Then, after two consecutive oxidation steps, the desired sulfonyl fluorides are formed (Scheme 20).

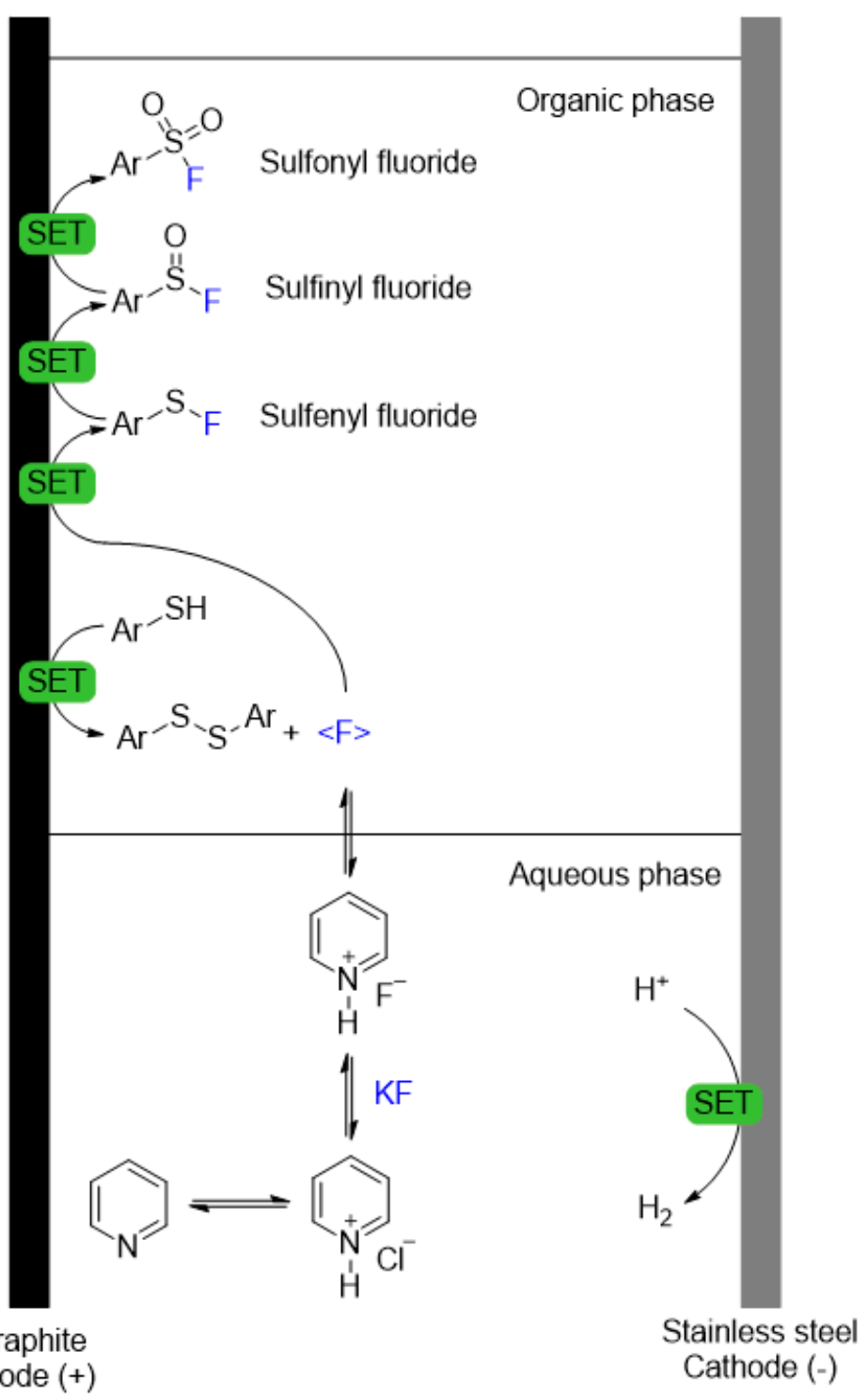

Scheme 20. Proposed mechanism for the electrochemical formation of sulfonyl fluorides from thiols or disulfides.

\subsection{Sulfonyl Fluorides Synthesis from Sulfonates and Sulfonic Acids}

Recently, the group of Qin and Sun used sulfonic acids and sulfonates as starting substrates to synthesize sulfonyl fluorides in a one-pot two-step procedure [55]. This method makes use of cyanuric chloride, as a source of chlorine, and $\mathrm{KHF}_{2}$, as a source of fluorine. This method is based on the formation of sulfonyl chlorides using cyanuric chloride in the presence of $5 \mathrm{~mol} \%$ of a catalyst (Tetrabutylammonium bromide TBAB or tetramethylammonium chloride TMAC) at $60{ }^{\circ} \mathrm{C}$ in acetonitrile. Then, $\mathrm{KHF}_{2}$ is added to exchange chlorine with fluorine and form the sulfonyl fluoride products. 
Various sodium sulfonate substrates, including electron-donating (22b and 22c), electron-withdrawing (22e) and aromatic (22f and $\mathbf{2 2 g}$ ) compounds, were tolerated with this method, yielding the desired products in moderate to good yields (Scheme 21a).

a)

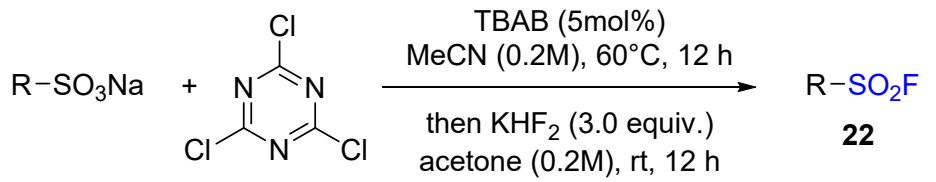

\section{Selected examples}<smiles>O=S(=O)(OF)c1ccccc1</smiles>

22a, $72 \%$<smiles>Cc1ccc(S(=O)(=O)F)cc1</smiles>

22b, $85 \%$<smiles>Cc1cc(C)c(S(=O)(=O)O)c(C)c1</smiles>

22c, $90 \%$<smiles>O=S(=O)(F)c1ccc(O)cc1</smiles>

22d, $64 \%$<smiles>O=[N+]([O-])c1cccc(S(=O)(=O)[O-])c1</smiles><smiles>O=S(=O)(OF)c1ccc2ccccc2c1</smiles>

22f, $93 \%$<smiles>O=S(=O)(O)c1cccc2ccccc12</smiles>

22g, $64 \%$

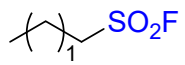

22h, $\mathrm{n}=3,68 \%$

22i, $n=7,83 \%$

22e, $45 \%$

$$
\text { (2) }
$$

b) $\mathrm{Ar}-\mathrm{SO}_{3} \mathrm{n}^{-} \mathrm{Ln}^{+}+\underset{\mathrm{Y} 3}{\stackrel{\mathrm{TBAB}(5 \mathrm{~mol} \%)}{\mathrm{MeCN}(0.2 \mathrm{M}), 60^{\circ} \mathrm{C}, 12 \mathrm{~h}}} \mathrm{Ar}-\mathrm{SO}_{2} \mathrm{~F}$

\section{Selected examples}
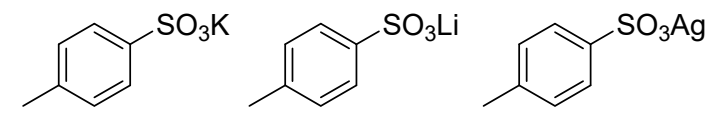

Y3a (22b, 85\%) Y3b (22b, 50\%)

Y3c (22b, 95\%)<smiles>Cc1ccc(S(N)(=O)=O)cc1</smiles><smiles></smiles>

Y3e (22b, 15\%)<smiles>Cc1ccc(S(=O)(=O)[O-])cc1</smiles>

Y3f (22b, 11\%)<smiles>CCCCCCCCCS(=O)(=O)c1ccc(C)cc1</smiles>

Y3g (22b, 2\%)

\section{TMAC (5mol\%)}

c)

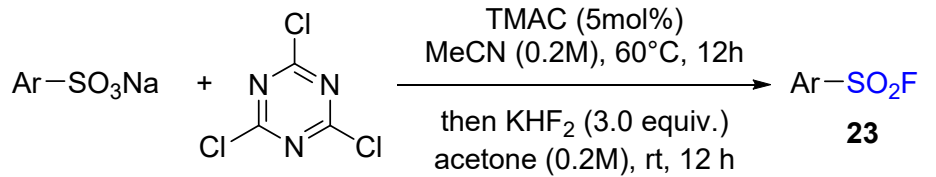

\section{Selected examples}<smiles>O=S(=O)(OF)c1ccccc1</smiles>

23a, $70 \%$<smiles>Cc1ccc(S(=O)(=O)F)cc1</smiles>

23b, $85 \%$<smiles>O=S(=O)(O)c1ccc(O)cc1</smiles>

23c, $62 \%$<smiles>O=S(=O)(OF)c1ccc2ccccc2c1</smiles>

23d, $74 \%$

Scheme 21. Synthesis of sulfonyl fluorides from sulfonates or sulfonic acids.

To test the effectiveness of this protocol, the authors examined a series of sulfonates containing several cations (Scheme 21b). The monovalent sulfonate salts Y3a-Y3d were easily converted to the corresponding sulfonyl fluorides with moderate to good yields. However, the sulfonate salts of the divalent metals $\mathbf{Y} \mathbf{3 e}-\mathbf{Y} \mathbf{3 g}$ reacted only slightly, resulting in poor yields. To widen the range of the substrates, they started from sulfonic acids 
as starting reagents using TMAC as catalyst instead of TBAB. A series of aryl sulfonic acids carrying electron-donating groups (23b and $23 \mathbf{c}$ ) were obtained with moderate to good yields. Naphthalene-2-sulfonyl fluoride was also obtained with a good yield 23d (Scheme 21c).

\subsection{Sulfonyl Fluorides Synthesis from Sulfonamides}

Very recently, the group of Cornella reported a direct method for the synthesis of sulfonyl fluorides from sulfonamides [56]. The method consists of forming sulfonyl chlorides from sulfonamides through activation with a pyrylium tetrafluoroborate $\left(\mathrm{Pyry} \mathrm{BF}_{4}\right)$ and $\mathrm{MgCl}_{2}$, and the subsequent in-situ conversion to sulfonyl fluorides by the addition of KF. The reactions were performed in $\mathrm{MeCN}$ at $60^{\circ} \mathrm{C}$ and the desired compounds were obtained with moderate to very good yields. The high chemoselectivity of Pyry- $\mathrm{BF}_{4}$ towards amino groups allows the formation of sulfonyl fluorides in complex structures. This was proven by examining a wide variety of complex sulfonamides containing various functionalities (Scheme 22).

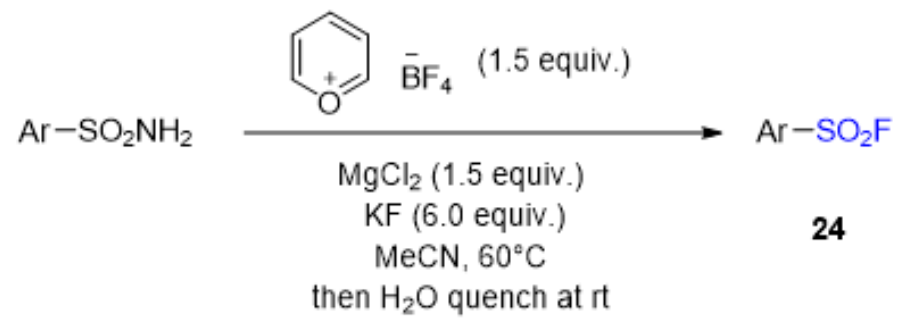

Aryl sulfonamides

Selected examples
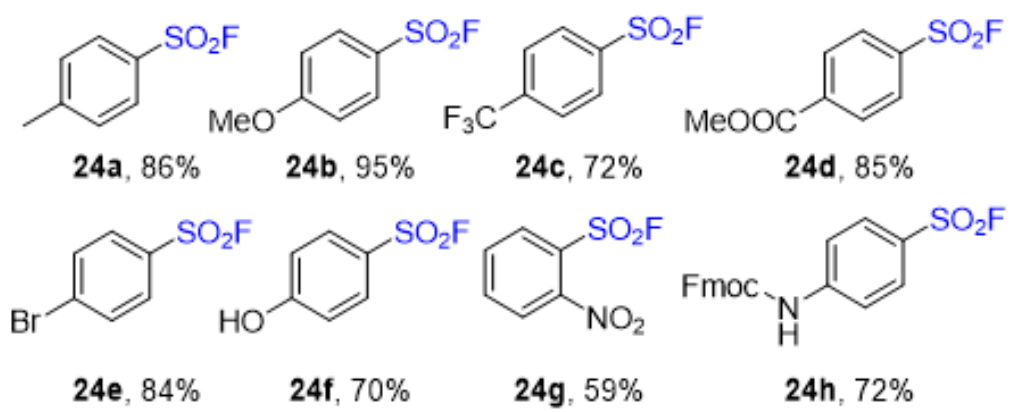

- Late-stage sulfonyl fluoride synthesis ..........<smiles>COc1ccc(Cl)cc1C(=O)NCCc1ccc(S(=O)(=O)F)cc1</smiles>

$24 \mathrm{~m}, 80 \%$<smiles>O=S(=O)(F)c1cc2c(cc1Cl)NCNS2(=O)=O</smiles>

Hydrochlorothiazide $24 n, 43 \%$<smiles>CCN1CCCC1CNC(=O)c1cc(S(F)(F)F)ccc1OC</smiles>

(t)-Sulpiride 24m, $80 \%$<smiles>Cc1ccc(-c2cc(C)nn2-c2ccc(S(F)(F)F)cc2)cc1</smiles>

Celecoxib 240, $90 \%$

Scheme 22. Synthesis of sulfonyl fluorides from sulfonamides. 


\section{Conclusions}

Arylsulfonyl fluorides are attracting considerable attention in modern organic chemistry due to their wide range of applications. Thus, developing new synthetic strategies towards the incorporation of the sulfonyl fluoride moiety is of high interest. We have described herein the existing methods to access fluorosulfonylated compounds using either direct or indirect methodologies. These various works offer different and versatile approaches to form such compounds, tolerating a large variety of functional groups. The easy access to the starting material/catalysts of the developed methodology will definitely foster the emergence of new applications.

Author Contributions: The manuscript was written through contribution of all the co-authors. All authors have read and agreed to the published version of the manuscript.

Funding: Financial support from the CNRS and the Agence Nationale de la Recherche (ANR-JCJC2020-CDI-DEOX) is gratefully acknowledged. D.L. thanks the French Ministry of Higher Education and Research for a doctoral fellowship.

Conflicts of Interest: The authors declare no conflict of interest.

\section{References}

1. Shannon, D.A.; Gu, C.; McLaughlin, C.J.; Kaiser, M.; van der Hoorn, R.A.L.; Weerapana, E. Sulfonyl fluoride analogues as activity-based probes for serine proteases. ChemBioChem 2012, 13, 2327-2330. [CrossRef] [PubMed]

2. Narayanan, A.; Jones, L.H. Sulfonyl fluorides as privileged warheads in chemical biology. Chem. Sci. 2015, 6, 2650-2659. [CrossRef]

3. Barrow, A.S.; Smedley, C.J.; Zheng, Q.; Li, S.; Dong, J.; Moses, J.E. The growing applications of SuFEx click chemistry. Chem. Soc. Rev. 2019, 48, 4731-4758. [CrossRef] [PubMed]

4. Fattah, T.A.; Saeed, A.; Albericio, F. Recent advances towards sulfur (VI) fluoride exchange (SuFEx) click chemistry. J. Fluor. Chem. 2018, 213, 87-112. [CrossRef]

5. Chinthakindi, P.K.; Arvidsson, P.I. Sulfonyl Fluorides (SFs): More Than Click Reagents? Eur. J. Org. Chem. 2018, 2018, 3648-3666. [CrossRef]

6. Lee, C.; Cook, A.J.; Elisabeth, J.E.; Friede, N.C.; Sammis, G.M.; Ball, N.D. The Emerging Applications of Sulfur(VI) Fluorides in Catalysis. ACS Catal. 2021, 11, 6578-6589. [CrossRef]

7. Grimster, N.P.; Connelly, S.; Baranczak, A.; Krasnova, L.B.; Powers, E.T.; Wilson, I.A.; Kelly, J.W.; Dong, J.; Sharpless, K.B. Aromatic Sulfonyl Fluorides Covalently Kinetically Stabilize Transthyretin to Prevent Amyloidogenesis while Affording a Fluorescent Conjugate. J. Am. Chem. Soc. 2013, 135, 5656-5668. [CrossRef]

8. Hett, E.C.; Xu, H.; Geoghegan, K.F.; Gopalsamy, A.; Kyne, R.E.; Menard, C.A.; Narayanan, A.; Parikh, M.D.; Liu, S.; Roberts, L.; et al. Rational targeting of active-site tyrosine residues using sulfonyl fluoride probes. ACS Chem. Biol. 2015, 10, 1094-1098. [CrossRef] [PubMed]

9. Gu, C.; Shannon, D.A.; Colby, T.; Wang, Z.; Shabab, M.; Kumari, S.; Villamor, J.G.; McLaughlin, C.J.; Weerapana, E.; Kaiser, M.; et al. Chemical proteomics with sulfonyl fluoride probes reveals selective labeling of functional tyrosines in glutathione transferases. Chem. Biol. 2013, 20, 541-548. [CrossRef]

10. Kruse, C.H.; Holden, K.G.; Pritchard, M.L.; Feild, J.A.; Rieman, D.J.; Greig, R.G.; Poste, G. Synthesis and Evaluation of Multisubstrate Inhibitors of an Oncogene-Encoded Tyrosine-Specific Protein Kinase. J. Med. Chem. 1988, 31, 1762-1767. [CrossRef]

11. Brouwer, A.J.; Alvarez, N.H.; Ciaffoni, A.; van de Langemheen, H.; Liskamp, R.M.J. Proteasome inhibition by new dual warhead containing peptido vinyl sulfonyl fluorides. Bioorg. Med. Chem. 2016, 24, 3429-3435. [CrossRef]

12. Inkster, J.A.H.; Liu, K.; Ait-Mohand, S.; Schaffer, P.; Guérin, B.; Ruth, T.J.; Storr, T. Sulfonyl Fluoride-Based Prosthetic Compounds as Potential 18F Labelling Agents. Chem. Eur. J. 2012, 18, 11079-11087. [CrossRef]

13. Matesic, L.; Wyatt, N.A.; Fraser, B.H.; Roberts, M.P.; Pham, T.Q.; Greguric, I. Ascertaining the suitability of aryl sulfonyl fluorides for [18F]radiochemistry applications: A systematic investigation using microfluidics. J. Org. Chem. 2013, 78, 11262-11270. [CrossRef] [PubMed]

14. Xiao, X.; Zhou, F.; Jiang, J.; Chen, H.; Wang, L.; Chen, D.; Xu, Q.; Lu, J. Highly efficient polymerization via sulfur(vi)-fluoride exchange (SuFEx): Novel polysulfates bearing a pyrazoline-naphthylamide conjugated moiety and their electrical memory performance. Polym. Chem. 2018, 9, 1040-1044. [CrossRef]

15. Yang, C.; Flynn, J.P.; Niu, J. Facile Synthesis of Sequence-Regulated Synthetic Polymers Using Orthogonal SuFEx and CuAAC Click Reactions. Angew. Chem. Int. Ed. 2018, 57, 16194-16199. [CrossRef] [PubMed]

16. Wang, H.; Zhou, F.; Ren, G.; Zheng, Q.; Chen, H.; Gao, B.; Klivansky, L.; Liu, Y.; Wu, B.; Xu, Q.; et al. SuFEx-Based Polysulfonate Formation from Ethenesulfonyl Fluoride-Amine Adducts. Angew. Chem. Int. Ed. 2017, 56, 11203-11208. [CrossRef] [PubMed]

17. Dong, J.; Krasnova, L.; Finn, M.G.; Sharpless, K.B. Sulfur(VI) Fluoride Exchange (SuFEx): Another Good Reaction for Click Chemistry. Angew. Chem. Int. Ed. 2014, 53, 9430-9448. [CrossRef] [PubMed] 
18. Qin, H.L.; Zheng, Q.; Bare, G.A.L.; Wu, P.; Sharpless, K.B. A Heck-Matsuda Process for the Synthesis of $\beta$-Arylethenesulfonyl Fluorides: Selectively Addressable Bis-electrophiles for SuFEx Click Chemistry. Angew. Chem. Int. Ed. 2016, 55, 14155-14158. [CrossRef]

19. Yatvin, J.; Brooks, K.; Locklin, J. SuFEx Click: New Materials from SOxF and Silyl Ethers. J. Chem. Eur. J. 2016, 22, 16348-16354. [CrossRef]

20. Dondoni, A.; Marra, A. SuFEx: A metal-free click ligation for multivalent biomolecules. Org. Biomol. Chem. 2017, 15, 1549-1553. [CrossRef]

21. Nielsen, M.K.; Ugaz, C.R.; Li, W.; Doyle, A.G. PyFluor: A Low-Cost, Stable, and Selective Deoxyfluorination Reagent. J. Am. Chem. Soc. 2015, 137, 9571-9574. [CrossRef]

22. Nielsen, M.K.; Ahneman, D.T.; Riera, O.; Doyle, A.G. Deoxyfluorination with Sulfonyl Fluorides: Navigating Reaction Space with Machine Learning. J. Am. Chem. Soc. 2018, 140, 5004-5008. [CrossRef]

23. Kice, J.L.; Lunney, E.A. Catalysis of the hydrolysis of aryl sulfonyl fluorides by acetate ion and trimethylamine. J. Org. Chem. 1975, 40, 2125-2127. [CrossRef]

24. Mukherjee, H.; Debreczeni, J.; Breed, J.; Tentarelli, S.; Aquila, B.; Dowling, J.E.; Whitty, A.; Grimster, N.P. A study of the reactivity of S(VI)-F containing warheads with nucleophilic amino-acid side chains under physiological conditions. Org. Biomol. Chem. 2017, 15, 9685-9695. [CrossRef] [PubMed]

25. Ciuffarin, E.; Senatore, L.; Isola, M. Nucleophilic substitution at four-co-ordinate sulphur. Mobility of the leaving group. J. Chem. Soc. Perkin Trans. 1972, 2, 468-471. [CrossRef]

26. Baker, R.B.; Lourens, G.J. Irreversible Enzyme Inhibitors. CV.12 Differential Irreversible Inhibition of Vertebrate Dihydrofolic Reductases by Derivatives of 4,6-Diamino-1,2-dihydro-2,2-dimethyl-1-phenyl-s-triazines Substituted with a Terminal Sulfonyl Fluoride. J. Med. Chem. 1967, 10, 1113-1122. [CrossRef] [PubMed]

27. Bertrand, M.P. Recent progress in the use of sulfonyl radicals in organic synthesis. A review. Org. Prep. Proced. Int. 1994, 26, 257-290. [CrossRef]

28. Chinthakindi, P.K.; Kruger, H.G.; Govender, T.; Naicker, T.; Arvidsson, P.I. On-Water Synthesis of Biaryl Sulfonyl Fluorides. J. Org. Chem. 2016, 81, 2618-2623. [CrossRef]

29. Davis, A.T.; Curto, J.M.; Bagley, S.W.; Willis, M.C. One-pot palladium-catalyzed synthesis of sulfonyl fluorides from aryl bromides. Chem. Sci. 2017, 8, 1233-1237. [CrossRef]

30. Tribby, A.L.; Rodriguez, I.; Shariffudin, S.; Ball, N.D. Pd-Catalyzed Conversion of Aryl Iodides to Sulfonyl Fluorides Using $\mathrm{SO}_{2}$ Surrogate DABSO and Selectfluor. J. Org. Chem. 2017, 82, 2294-2299. [CrossRef]

31. Kwon, J.; Kim, B.M. Synthesis of Arenesulfonyl Fluorides via Sulfuryl Fluoride Incorporation from Arynes. Org. Lett. 2019, 21, 428-433. [CrossRef] [PubMed]

32. Lee, C.; Ball, N.D.; Sammis, G.M. One-pot fluorosulfurylation of Grignard reagents using sulfuryl fluoride. Chem. Commun. 2019, 55, 14753. [CrossRef] [PubMed]

33. Liu, Y.; Yu, D.; Guo, Y.; Xiao, J.; Chen, Q.; Liu, C. Arenesulfonyl Fluoride Synthesis via Copper-Catalyzed Fluorosulfonylation of Arenediazonium Salts. Org. Lett. 2020, 22, 2281-2286. [CrossRef]

34. Zhong, T.; Pang, M.; Chen, Z.; Zhang, B.; Weng, J.; Lu, G. Copper-free Sandmeyer-type Reaction for the Synthesis of Sulfonyl Fluorides. Org. Lett. 2020, 22, 3072-3078. [CrossRef] [PubMed]

35. Louvel, D.; Chelagha, A.; Rouillon, J.; Payard, P.-A.; Khrouz, L.; Monnereau, C.; Tlili, A. Metal-Free Visible-Light Synthesis of Arylsulfonyl Fluorides: Scope and Mechanism. Chem. Eur. J. 2021, 27, 8704-8708. [CrossRef] [PubMed]

36. Louvel, D.; Ghiazza, C.; Debrauwer, V.; Khrouz, L.; Monnereau, C.; Tlili, A. Forging C-SeCF 3 Bonds with Trifluoromethyl Tolueneselenosulfonate under Visible-Light. Chem. Rec. 2021, 21, 417-426. [CrossRef]

37. Ghiazza, C.; Debrauwer, V.; Monnereau, C.; Khrouz, L.; Médebielle, M.; Billard, T.; Tlili, A. Visible-Light-Mediated Metal-Free Synthesis of Trifluoromethylselenolated Arenes. Angew. Chem. Int. Ed. 2018, 57, 11781-11785. [CrossRef]

38. Ghiazza, C.; Monnereau, C.; Khrouz, L.; Médebielle, M.; Billard, T.; Tlili, A. New Avenues in Radical Trifluoromethylselenylation with Trifluoromethyl Tolueneselenosulfonate. Synlett 2019, 30, 777-782. [CrossRef]

39. Ghiazza, C.; Khrouz, L.; Monnereau, C.; Billard, T.; Tlili, A. Visible-light promoted fluoroalkylselenolation: Toward the reactivity of unsaturated compounds. Chem. Commun. 2018, 54, 9909-9912. [CrossRef]

40. Ghiazza, C.; Khrouz, L.; Billard, T.; Monnereau, C.; Tlili, A. Fluoroalkylselenolation of Alkyl Silanes/Trifluoroborates under Metal-Free Visible-Light Photoredox Catalysis. Eur. J. Org. Chem. 2020, 1559-1566. [CrossRef]

41. Bianchi, T.A.; Cate, L.A. Phase Transfer Catalysis. Preparation of Aliphatic and Aromatic Sulfonyl Fluorides. J. Org. Chem. 1977, 42, 2031-2032. [CrossRef]

42. Talko, A.; Barbasiewicz, M. Nucleophilic Fluorination with Aqueous Bifluoride Solution: Effect of the Phase-Transfer Catalyst. ACS Sustain. Chem. Eng. 2018, 6, 6693-6701. [CrossRef]

43. Tang, L.; Yang, Y.; Wen, L.; Yang, X.; Wang, Z. Catalyst-free radical fluorination of sulfonyl hydrazides in water. Green Chem. 2016, 18, 1224-1228. [CrossRef]

44. Wright, S.W.; Hallstrom, K.N. A Convenient Preparation of Heteroaryl Sulfonamides and Sulfonyl Fluorides from Heteroaryl Thiols. J. Org. Chem. 2006, 71, 1080-1084. [CrossRef] [PubMed] 
45. Kirihara, M.; Naito, S.; Nishimura, Y.; Ishikuza, Y.; Iwai, T.; Takeuchi, H.; Ogata, T.; Hanai, H.; Kinoshita, Y.; Kishida, M.; et al. Oxidation of disulfides with electrophilic halogenating reagents: Concise methods for preparation of thiosulfonates and sulfonyl halides. Tetrahedron 2014, 70, 2464-2471. [CrossRef]

46. Laudadio, G.; Bartolomeu, A.d.A.; Verwijlen, L.M.H.M.; Cao, Y.; de Oliveira, K.T.; Noël, T. Sulfonyl Fluoride Synthesis through Electrochemical Oxidative Coupling of Thiols and Potassium Fluoride. J. Am. Chem. Soc. 2019, 141, 11832-11836. [CrossRef] [PubMed]

47. Waldvogel, S.R.; Lips, S.; Selt, M.; Riehl, B.; Kampf, C.J. Electrochemical Arylation Reaction. Chem. Rev. 2018, 118, 6706-6765. [CrossRef]

48. Yan, M.; Kawamata, Y.; Baran, P.S. Synthetic Organic Electrochemistry: Calling All Engineers. Angew. Chem. Int. Ed. 2018, 57, 4149-4155. [CrossRef]

49. Wiebe, A.; Gieshoff, T.; Möhle, S.; Rodrigo, E.; Zirbes, M.; Waldvogel, S.R. Electrifying Organic Synthesis. Angew. Chem. Int. Ed. 2018, 57, 5594-5619. [CrossRef]

50. Sauermann, N.; Meyer, T.H.; Ackermann, L. Electrochemical Cobalt-Catalyzed C-H Activation. Chem. Eur. J. 2018, $24,16209-16217$. [CrossRef]

51. Yan, M.; Kawamata, Y.; Baran, P.S. Synthetic Organic Electrochemical Methods Since 2000: On the Verge of a Renaissance. Chem. Rev. 2017, 117, 13230-13319. [CrossRef]

52. Pitts, C.R.; Bornemann, D.; Liebing, P.; Santschi, N.; Togni, A. Making the $\mathrm{SF}_{5}$ Group More Accessible: A Gas-Reagent-Free Approach to Aryl Tetrafluoro- $\lambda 6$-sulfanyl Chlorides. Angew. Chem. Int. Ed. 2019, 58, 1950-1954. [CrossRef] [PubMed]

53. Umemoto, T.; Garrick, L.M.; Saito, N. Discovery of practical production processes for arylsulfur pentafluorides and their higher homologues, bis- and tris(sulfur pentafluorides): Beginning of a new era of "super-trifluoromethyl" arene chemistry and its industry. J. Org. Chem. 2012, 8, 461-471. [CrossRef] [PubMed]

54. Umemoto, T.; Singh, R.P.; Xu, Y.; Saito, N. Discovery of 4-tert-Butyl-2,6-dimethylphenylsulfur Trifluoride as a Deoxofluorinating Agent with High Thermal Stability as Well as Unusual Resistance to Aqueous Hydrolysis, and Its Diverse Fluorination Capabilities Including Deoxofluoro-Arylsulfinylation with High Stereoselectivity. J. Am. Chem. Soc. 2010, 132, 18199-18205. [PubMed]

55. Jiang, Y.; Alharbi, N.S.; Sun, B.; Qin, H. Facile one-pot synthesis of sulfonyl fluorides from sulfonates or sulfonic acids. RSC Adv. 2019, 9, 13863-13867. [CrossRef]

56. Pérez-Palau, M.; Cornella, J. Synthesis of Sulfonyl Fluorides from Sulfonamides. J. Eur. J. Org. Chem. 2020, 2020, 2497-2500. [CrossRef] 